\title{
Арефинкина Е.Г.
}

К вопросу о принципе индивидуализации назначения

\author{
наказания и специфике его применения к \\ несовершеннолетним
}

\author{
Arefinkina E.G. \\ To the question of the punishment individualization principle and \\ peculiarities of its application to the minors
}

В статье рассматривается проблематика индивидуализации наказания в действующем законодательстве и практике, необходимость учета специфики возраста несовершеннолетних и их психологических особенностей при назначении наказания данной возрастной категории, а также анализируются сложившаяся судебная практика и базовые отличия индивидуализации от дифференциации наказания

Ключевые слова: несовершеннолетний, преступление, уголовный закон, наказание, индивидуализация, правила назначения наказания, справедливость наказания

Арефинкина Екатерина Геральдовна

Кандидат юридических наук, доцент, зав. кафедрой Российский университет дружбы народов г. Сочи, ул. Куйбышева, 32
The article deals with a problem of punishment individualization in current legislation and practice, necessity to take into account the minors age-related and psychological peculiarities when imposing sentence. Also the article examines the current judicial practice and basic differences between punishment individualization and differentiation

Key words: minor, crime, criminal law, punishment, individualization, the rules of assignment of the punishment, the justice of the punishment

Arefinkina Ekaterina Geraldovna

Candidate of Juridical Sciences, Associate Professor, Head of Department

Peoples' friendship university of Russia Sochi, Kuibysheva st., 32

Одна из центральных проблем теории наказания - обеспечение его индивидуализации. Назначение справедливого наказания связывается с авторитетом и уважением к государству, властям, уголовному закону и суду. Необоснованная репрессия, впрочем, как и неоправданно мягкое наказание, практически в равной степени влекут за собой негативные последствия.

Проблематика преступности несовершеннолетних и наказуемости их деяний постоянно находится в центре пристального внимания ученых и юристовпрактиков. Периодические изменения законодательства в рассматриваемой части свидетельствуют о намерении государства укреплять законность и правопорядок в борьбе с преступностью несовершеннолетних, где немаловажное место отводится совершенствованию системы уголовных наказаний и повышению ее эффективности. 
Ряд теоретиков и практиков, ссылаясь на отсутствие реальной альтернативы лишению свободы, делают упор на катастрофический рост детской преступности, ее официальную динамику, и в связи с этим отрицают возможность либерализации карательной политики в отношении несовершеннолетних, обосновывая при этом обязанность подростков нести равное со взрослыми наказание за совершенные ими преступления принципами законности, справедливости и равенства перед законом.

Однако именно при таком подходе и невозможно назначение справедливого наказания с учетом индивидуализации, так как в этом случае абсолютно не учитываются специфические особенности подросткового возраста.

С другой стороны, верно и то, что проявлять чрезмерную мягкость и гуманность к преступнику, хотя и несовершеннолетнему, было бы слишком преждевременно и необоснованно.

Наказание является справедливым только в том случае, когда характер применяемых мер принуждения и объем возлагаемой ответственности соответствуют общественной опасности правонарушения, особенностям личности правонарушителя и обстоятельствам, смягчающим либо отягчающим его ответственность, то есть строго индивидуализированы.

Следовательно, индивидуализация назначения наказания несовершеннолетним - это прежде всего ориентирование его мер на достижение социально полезных изменений в личности правонарушителя.

Являясь комплексной межотраслевой идеей, индивидуализация с полным основанием может быть названа в качестве принципа назначения наказания.

Индивидуализация направлена именно на личность. Однако в настоящий момент законодатель, а вслед за ним и правоприменитель, исследуя собственно правовые (характер и степень общественной опасности совершенного правонарушения и несовершеннолетнего правонарушителя) и социально-демографические, в том числе пол, возраст, род занятий, социальные роли и другие факторы, не учитывают за редким исключением ярких психологических аспектов правонарушения. Тем самым закон игнорирует значительные возможности для индивидуализации назначения наказания несовершеннолетним, не использует всего арсенала средств для предупреждения правонарушений в их среде, что в конечном счете негативно отражается на состоянии борьбы с преступностью, мешает достичь эффективного исправления и перевоспитания правонарушителей.

Как уже было сказано, значительную роль в индивидуализации назначения наказания играют психологические факторы. Они явно либо опосредованно присутствуют во всех элементах состава правонарушения. Поэтому без комплексного психологического анализа личности несовершеннолетнего правонарушителя, а в некоторых случаях и особенностей правонарушения, трудно обоснованно и справедливо решить вопрос об индивидуализации назначения наказания и его исполнения, а, следовательно, достичь поставленных перед институтом назначения наказания целей. Ведь сегодня вся правовая политика и, прежде всего, уголовная как никогда должна быть направлена на охрану и защиту прав и свобод человека, на справедливость и гуманность наказания, а, 
следовательно, и на индивидуализацию его назначения, что, в конечном итоге, обеспечит построение правовой государственности.

Сущность принципа индивидуализации назначения наказания несовершеннолетним заключается в необходимости строгого и последовательного учета черт конкретного правонарушения, его субъекта, выбора такого вида и размера наказания, который наиболее точно соответствовал выявленным особенностям в целях достижения оптимальных результатов для воздействия на сознание и поведение правонарушителя, предупреждение правонарушений.

Требование индивидуализации назначения наказания несовершеннолетним обязывает компетентный государственный орган (должностное лицо) строго индивидуально подходить к рассмотрению конкретного дела на этапе назначения наказания.

Более того, именно принцип индивидуализации, воплощая в себе начала справедливости и гуманизма, позволяет не только избрать наиболее отвечающие тяжести содеянного и личностным особенностям субъекта вид и размер наказания, но и на любом этапе развития прекратить само его осуществление, если подобное решение, не противореча требованиям неотвратимости, законности и обоснованности правового воздаяния, способно наилучшим образом отразиться на достижении целей назначения наказания.

Игнорирование же требований индивидуализации ведет к снижению эффективности назначенного наказания, нередко служит причиной правоприменительных ошибок, связанных, в частности, с применением неоправданно суровых либо слишком мягких мер наказания.

Следует отметить, что концепция принципа индивидуализации назначения наказания появилась сравнительно недавно. Позитивистское понимание права, ориентирование прежде всего на обеспечение интересов государства, отождествление понятий «право» и «закон», «ответственность» и «наказание» затмевало индивидуализацию и по сути подменяло ее анализом общеотраслевых начал назначения наказания, причем в большинстве случаев лишь с формальных юридических позиций. Все это приводило у тому, что принцип индивидуализации назначения наказания рассматривался как требование формального (можно сказать, механического) учета нормативных положений, касающихся тех или иных сторон деяния и его субъекта.

Сегодня все больше исследователей уделяют внимание вопросам индивидуализации назначения наказания. Однако следует признать, явно недостаточную степень разработанности данной проблемы, особенно применительно к несовершеннолетним. Исследования индивидуализации назначения наказания несовершеннолетним носят в большинстве случаев частный, прикладной характер и заключаются в основном в комментировании конкретно-отраслевых норм - общих начал назначения наказания и специфики их применения к несовершеннолетним. При этом из поля зрения выпадают иные, имеющиеся в отраслевом законодательстве специальные правила и приемы, критерии индивидуализации назначения наказания. Не выходя за рамки процесса назначения наказания несовершеннолетним, исследования ограничиваются формально-юридическим анализом соответствующих норм. 
В юридической литературе и ряде нормативных актов индивидуализация тесно связывается с дифференциацией наказания. И это не случайно, так как индивидуализация и дифференциация наказания являются важнейшими идеями современной правоохранительной политики.

Несмотря на их тесную взаимосвязь, эти категории имеют различную правовую природу.

Дифференциация (от лат. differenia) - разность, различие, разделение, расчленение целого на части, формы и ступени [1, С. 401], что применительно к наказанию будет означать назначение различных его видов за различные правонарушения. С этой целью устанавливается, прежде всего, система наказаний (ст. 43-59 УК РФ). Дифференциация наказания внутри данной системы проводится на основе установления основных, дополнительных и смешанных (выступающих как основными, так и дополнительными) видов наказаний, а также путем установления предельных сроков и размеров данных видов в санкциях статей Особенной части УК РФ. Это сфера законодателя, который определяет общие (абстрактные) рамки наказуемости отдельных человеческих поступков.

Индивидуализация наказания - назначение наказания в пределах установленных законом санкций с учетом характера и степени общественной опасности совершенного преступления, личности виновного, обстоятельств, предусмотренных законом в качестве смягчающих или отягчающих ответственность [2, С. 248-249]. Индивидуализация наказания осуществляется судом в отношении лица, признанного виновным в совершении преступления, на этапе непосредственного назначения наказания, с учетом критериев его назначения, указанных в ч. 3 ст. 60 УК РФ.

Все выше изложенное позволяет нам разграничить дифференциацию и индивидуализацию наказания несовершеннолетних по следующим признакам [3, С. 185]:

- по субъекту (дифференциация наказания осуществляется законодателем, а индивидуализация - судом);

- по направленности (дифференциация наказания проводится в отношении неопределенного круга лиц, являющихся несовершеннолетними, которые совершили либо совершат в будущем общественно опасные деяния, а индивидуализация наказания - в отношении конкретного несовершеннолетнего лица, признанного судом виновным в совершении преступления);

- по итоговому акту (дифференциация наказания проводится законодателем в уголовном законе - УК РФ, а актом индивидуализации наказания, назначаемого несовершеннолетнему, выступает решение суда в виде приговора, постановления, определения).

Нередко индивидуализацию назначения наказания отождествляют с персонификацией наказания, что, на наш взгляд, совершенно неприемлемо. В то время, как понятие «персональный» означает нечто, касающееся только отдельного лица, содержание термина «индивидуальность» глубже и указывает на совокупность индивидуальных черт и свойств. Строго говоря, «персонифицировать» - это значит установить конкретное лицо, связанное с тем или иным событием, а «индивидуализировать»- выявить те элементы, которые составляют характеристики данного лица. 
Таким образом, принцип индивидуализации назначения наказания несовершеннолетним - требование максимальной персональной обращенности мер, применяемых а отношении несовершеннолетних правонарушителей. Он направлен не только на обеспечение справедливости воздаяния за содеянное (в виде установления соразмерности между тяжестью правонарушения и карой за него), но и на реализацию воспитательных и ресоциализаторских (социальноадаптационных) задач наказания.

Герасимов И Т. справедливо подчеркивает, что не может быть "беспредметного" теоретического изучения, оно всегда должно быть направлено на реальные объекты [4, С. 123]. Проверка теории практикой это непрерывный процесс, поскольку последняя может выступать и источником теоретических знаний, и критерием их истинности.

Френсис Бэкон писал, что "... в законе немало скрыто того, что значительно заметнее и яснее проявляется в процессуальных формулах. Если первый можно сравнить с кулаком, то вторые следует сравнить с раскрытой ладонью" [5, С. 508]. В связи с этим, проверить достаточную логическую стройность законодательного материала, а также значимость приведенных выше теоретических построений можно лишь опираясь на правоприменительную практику.

Достижение таких целей наказания, как исправление осужденного и предупреждение совершения им новых преступлений во многом зависит от оценки назначенного наказания виновным. В процессе исполнения наказания количество осужденных несовершеннолетних, считающих назначенное им наказание справедливым, должно увеличиваться, ведь восприятие назначенного наказания как справедливого акта является необходимой предпосылкой исправления осужденного. Но чтобы добиться этого, нужен справедливый приговор, вынесенный виновному.

Анализ судебной практики федеральных судов г. Сочи показал, что индивидуализация назначения наказания несовершеннолетним зачастую осуществляется некачественно, поверхностно. Из 200 изученных приговоров 65 \% содержали лишь ссылку на учет общественной опасности совершенного преступленияb несовершеннолетний возраст, что не соответствует требованиям назначения законного и справедливого наказания. Суд обязан в каждом конкретном случае детально индивидуализировать назначаемое наказание, указывать, какие именно конкретные обстоятельства повлияли на размер и вид назначенного наказания, какие именно личностные характеристики несовершеннолетнего, а также какие условия жизни и воспитания его в семье были учтены при вынесении приговора по делу.

Изучение судебной практики показало, что при назначении наказания суды нередко учитывают те данные о личности виновного несовершеннолетнего, которые не отразились и (или) не проявились в преступлении. По нашему мнению, суд является заложником сложившейся ситуации, когда в материалах уголовного дела отсутствуют полноценные данные о личности обвиняемого, причинах и условиях совершения преступлений. Тем не менее, такой судебный акт не может являться обоснованным и выглядит неубедительным как для об- 
щественного мнения, так и для несовершеннолетнего осужденного. Индивидуализация наказания в большинстве случаев осуществляемая путем включения в приговор формулировки: «...при назначении наказания были учтены все обстоятельства дела, степень общественной опасности совершенного преступления, личность подсудимого, который ранее не был судим и характеризуется положительно, а также его несовершеннолетний возраст», - попросту недопустима. Бессистемное и формальное изложение судом данных, которые повиляли на назначение наказания, не способствует его эффективности, что недопустимо, и в ряде случаев служит основанием к отмене приговора.

\section{Список используемых источников:}

1. Советский энциклопедический словарь. М., 1990. С. 401.

2. Большой юридический словарь. М., 1999. С. 248-249.

3. Чугаев А.П. Назначение наказания. Краснодар: Кубанский государственный университет, 2003. С. 185 4. Герасимов И.Г. Структура научного исследования (философский анализ познавательной деятельности в науке). М., 1985. С. 123.

5. Бэкон Ф. О достоинстве и приращении наук. Т. 1. М., 1977. С.508.

(C) 2016, Арефинкина Е.Г. К вопросу о принципе индивидуализации назначения наказания и специфике его применения к несовершеннолетним
(C) 2016, Arefinkina E.G.

To the question of the punishment individualization principle and peculiarities of its application to the minors 